\title{
КОНЦЕПТУАЛЬНИЙ ПРОСТІР ТЕКСТУ НОВОГО ЗАВІТУ
}

\author{
ЛАРИСА ШЕВЧЕНКО \\ Український мовно-інформаційний фонд \\ Національної академії наук України, Київ - Україна; \\ PRZESTRZEŃ KONCEPTUALNA TEKSTU NOWEGO TESTAMENTU
}

\author{
LARYSA SZEWCZENKO \\ Ukraiński Fundusz Językowo-Informacyjny Narodowej Akademii Nauk Ukrainy, \\ Kijów - Ukraina.
}

STRESZCZENIE. Artykuł poświęcony jest analizie poszczególnych konceptów w kontekście tekstowej całości. W pracy badano relacje głównych tematów i idei utworu ze strukturami konceptualnymi, które skupiają sensy pól tekstowych słów kluczy. Zaproponowana metodologia pozwala pokazać sens warstwy głębokiej tekstu określany przez konceptosferę utworu.

\section{CONCEPTUAL SPACE OF THE NEW TESTAMENT'S TEXT}

\section{LARYSA SHEVCHENKO}

Ukrainian Lingual-Informational Fund of the National Academy of Sciences of Ukraine, Kyiv - Ukraine

ABSTRACT. This article is dedicated to the concepts research in the context of a text space. The proposed method shows the means of explication of deep textual meanings, which were formed by the Testament's sphere of concepts.

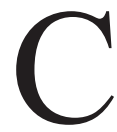

ьогодні дослідженню концепту присвячена величезна кількість наукових робіт. Він став ключовим терміном когнітивної лінгвістики, лінгвокультурології, психолінгвістики, власне лінгвістики, лінгвофілософії та ін. У мовознавстві спостерігаємо різноманітність підходів до визначення концепту, дискусій про його статус, багатство концептуальних досліджень. Популярність таких студій пояснюється тим, що відбувся активний перехід від панівної системно-структурної наукової парадигми, розгляду мови як строго структурованої системи фонетичних, граматичних і лексичних явищ до нової наукової парадигми, яка отримала назву функціонально-діяльнісного мовознавства, від лінгвістики, що орієнтована на вивчення мови „самої в собі”, до лінгвістики антропоцентричної, яка вивчає мову в зв'язку з людиною, його культурою, мисленням і свідомістю, тобто до когнітивної лінгвістики. Процес пізнання людиною дійсності когнітивна лінгвістика розглядає як процес утворення смислів, або концептів, про об'єкти пізнання, формування інформації про них, унаслідок чого утворюється система уявлень про світ, тобто сконструйована людиною концептуальна система. Концептуальні розвідки спрямовані на вирішення таких фундаментальних проблем, як структури репрезентації знань про світ і способи їхньої концептуалізації в мові. 
Велика кількість підходів до вивчення концепту породжує чимало питань і проблем, що вимагають системного осмислення цього поняття. Адже, незважаючи на значну концептологічну активність, відчувається певний брак досліджень, орієнтованих на операціональні аспекти концептології, тобто такі, де базові концентратори смислів, якими є концепти, разом із їхніми змістовими репрезентаціями будувалися б як результат застосування певних універсальних, проте добре визначених формалізованих теоретичних схем. Саме на цьому шляху можна досягти максимальної об'єктивності концептуального аналізу i, отже, концептуального опису дійсності та позбутися відчуття випадковості, що супроводжує чимало концептологічних структур.

Вочевидь, максимальної об’єктивності вивчення концептуальних моделей можна досягти тоді, коли вивести їх у площину текстових структур, текстових побудов. Концепти, активно задіяні в процесах комунікації, когнітивних процесах людини і суспільства, можна розцінювати як складну організовану сутність, що дає змогу використовувати їх для аналізу великих мовних масивів. Концептуальна інформація семантично виводиться 3 усього тексту як структурно-смислового і комунікативного цілого. Метою такого дослідження $€$ побудова концептуальної моделі твору як динамічного утворення, що інтегрує різнорідні текстові компоненти в єдине смислове ціле. Науковці наголошують на настійній необхідності такого підходу: „На сьогодні концептуальний аналіз активно використовують переважно в лексиці та фразеології. У галузі лінгвістичного аналізу тексту він перебуває в стадії розробки. Можна відзначити, що вже $є$ зразки концептуального аналізу окремих слів тексту або сукупності невеликих текстів (прислів’їв, приказок), але на сьогодні відсутня модель концептуального аналізу цілого тексту, хоча є серйозні спостереження і переконливо доведені теоретичні положення, які дають змогу ставити проблему концептуального аналізу художнього тексту"1.

Аналізуючи поняття ,текст”, визначаючи його природу, учені зосереджують увагу на його основоположній ролі бути засобом вербальної комунікації, прагматичних інтенціях, використанні його як знаряддя дії, впливу і взаємодії, тобто справедливо акцентують передусім на його орієнтованість на виконання запланованого автором завдання. Комунікативно-прагматичний аспект уважають актуальним напрямком дослідження тексту, оскільки він відкриває великі можливості для з'ясування сукупності лінгвістичних текстових засобів, спрямованих на читача, що організовані з певними намірами і цілями, адже мета текстової інформації пов'язана 3 прагненням вплинути на певні аспекти адресата — його емоційну та інтелектуальну сфери, оцінки, вчинки та ін. Саме вона детермінує вибір засобів для реалізації творчого процесу, унаслідок якого з'являється текст. Так, комунікативні наміри автора щодо читача О. Селіванова вважає основним текстотвірним чинником. Вони, на ії думку, відіграють вирішальну роль у формуванні структурно-семантичних, композиційних та інших текстових особливостей: „В останньому двадцятиріччі XX ст. в лінгвістичній науці на перший план вийшла окреслена раніше тенденція до вивчення тексту як складного комунікативного механізму, посередника комунікації, що фіксує стратегічну програму адресанта, яка сприймається й інтерпретується адресатом"2. Про актуальність інтерпретації текстових побудов, виходячи 3 їхнього прагматично-

${ }^{1}$ Л. Г. Бабенко и др., Лингвистический анализ художественного текста, Екатеринбург 2000, c. 55.

${ }^{2}$ Е. А. Селиванова, Основы лингвистической теории текста и коммуникаиии, Киев 2002 , c. 10. 
го начала, йдеться в дослідженнях О. Кубрякової: „Хоча в текстовому аналізі семантичний простір можна замкнути ним самим, обмежуючи спостереження внутрішньотекстовими зв'язками і працюючи всередині безпосередньої даності тексту, сьогодні переважає дискурсивний аналіз, у якому той самий семантичний простір розглядають як зв'язаний тисячами ниток із умовами його створення, метою і завданнями цього тексту, у зв' язку з аналогічними для нього текстами і т. п."3. А сам текст авторка трактує як ,інформаційно самодостатнє мовне повідомлення з ясно оформленою цілеспрямованістю й орієнтоване за своїм задумом на свого адресата"4. Значення комунікативної мети підкреслює О. Каменська, яка наголошує, що ланцюжок ,автор — текст — реципієнт” є квантом мовленнєвого твору, де розрізняють два види мовно-мисленнєвої діяльності письменника - перетворення „думка - текст”.

У вивченні прагматичних засад тексту, його смислового портрета, індивідуально-авторської концепції, закладеної в ньому, можуть бути ефективно задіяні методики концептуального аналізу. Багато досліджень тексту об'єднує комунікативно-діяльнісний підхід до цього об'єкта як до форми комунікації та явища ідіостилю з урахуванням його структури, семантики й прагматики. Розуміння твору науковці насамперед пов'язують із усвідомленням його концептуальної системи, що відображає світобачення автора, певні тенденції у відборі та використанні мовних засобів, містить важливе смислове та емоційно-оцінне навантаження. Якщо раніше лінгвісти обмежувались інтерпретацією стилістичного використання мовних одиниць тексту, не піднімаючись до висот аналізу його змістовного простору, то сьогодні вони все частіше акцентують на значущості дослідження його концептосфери. „Один із перспективних напрямів концептуального аналізу — використання його у вивченні семантичної організації художнього тексту"6. Кожний окремий твір утілює особливий варіант концептуалізації світу. Сама природа концептів — їхня структурна організація, відкритість до текстового наповнення, здатність концентровано виражати текстовий зміст дає змогу бачити в них важливий інструмент для дослідження творів.

Не можна не погодитись із думкою Д. Лихачова про те, що коли обмежуватися зверненням лише до словникового смислу слова, то смисл зашифрованого в художній формі послання автора залишиться для читача абсолютно неясним. Тільки оперування концептами й проникнення в індивідуально-авторську концептосферу дозволяє читачеві та дослідникові зрозуміти суть текстового змісту? Такі учені, як І. Гальперін, В. Кухаренко, В. Красних, Н. Болотнова та ін., ототожнюють концепт з ідеєю твору. Вони трактують концепт як „глибинний зміст, згорнуту смислову структуру тексту, що $є$ втіленням інтенції та через неї - мотиву діяльності автора, які приводять до породження тексту"в. Дослідники бачать концептуально вмотивовану текстову структуру, що відображає зв’язки й відношення мовних одиниць. Дані концептуального аналізу дають змогу ви-

${ }^{3}$ Е . С. Кубрякова, Язык и знание: На пути получения знаний о языке: Части речи с когнитивной точки зрения. Роль языка в познании мира, Москва 2004, с. 517.

${ }^{4}$ Е. С. Кубрякова, О тексте и критериях его определения, [в:] Текст. Структура и семантика, Москва 2001, т. 1, с. 73.

${ }^{5}$ О. Л. Каменская, Текст и коммуникация,, Москва 1990, с. 68.

6 Л. Г. Бабенко и др., Указан источник, с. 57.

7 Д. С. Лихачев, Концептосфера русского языка, [в:] Русская словесность. От теории словесности к структуре текста: антология, Москва 1997, с. 285.

${ }^{8}$ В. В. Красных, От кониепта к тексту и обратно, [в:] „Вестник Московского университета. Сер. Филология”, Москва 1998, № 1, с. 25. 
значити комунікативну орієнтованість тексту на адресата — принципи відбору та організації „мовних засобів різних рівнів у їхному текстовому втіленні з урахуванням не тільки мовної системи, що „стоїть” за текстом, але й мовленнєвої системності, обумовленої авторським задумом"я.

Отже, концепти заслуговують найпильнішої уваги з боку лінгвістів, оскільки є важливими компонентами текстової організації. Можна стверджувати, що прагматична орієнтованість твору, а також світогляд, авторська картина світу, провідні теми та ідеї репрезентовні у вигляді системи його концептів.

Маркери концептуального комплексу втілюються в тексті через множину так званих ключових слів. Відомо, що однією із прагматичних ознак значущості певного слова в тексті є висока частотність його вживання. Картина світу, відображена у творі, $є$ репрезентантом мовної закономірності, яка виявляється в тому, що інформативно важливі предмети і явища отримують досить вагому репрезентацію в тексті, посідають у ньому провідні позиції завдяки функціонуванню в статусі ключових слів. Комунікативну орієнтованість тексту, його вплив на адресата Ю. Караулов пов'язує саме із наявністю ключових слів: „численні повтори деяких слів, суттєві відхилення в їхній частоті певним чином впливають на читача, формуючи сприймання" 10 . Він наголошує, що істотним для розуміння ідіостилю і впливу на читача $є$ не показник абсолютної частоти цього слова, а якісні характеристики контекстів його вживання і розподіл цих контекстів у текстовому просторі.

Завдяки високій повторюваності, ключові слова займають домінантне положення як найвагоміший елемент текстової тканини: вони виокремлюються смисловою ускладненістю, характеризуються багатоплановістю, є концентрованим вираженням концептуального змісту. Це особлива категорія текстових елементів, стрижневим компонентом організації та функціонування якої $\epsilon$ авторський задум: „Під ключовими словами розуміють найбільш значущі в ідейно-художньому і прагматичному відношенні лексичні одиниці, з наміром актуалізовані автором, які є „вузловими ланцюгами” в асоціативно-змістовній мережі тексту. Це своєрідні „точки контакту” автора і читача, які регулюють читацьку діяльність стосовно комунікативної стратегії автора. Властивостями ключових слів є великий комунікативний і прагматичний потенціал, а також текстотвірна значущість"11.

Ключові слова мають низку суттєвих ознак, що дають змогу диференціювати їх на тлі інших текстових лексичних одиниць. Такими ознаками є: 1) високий ступінь повторюваності цих слів у тексті; 2) семантична місткість, якою слова наділені в контексті та яка дозволяє вибудовувати зв'язки між ключовими словами і лексемами, пов'язаними з ними семантично; 3) здатність конденсувати, згортати інформацію, виражену відповідною частиною тексту, а також усім текстом загалом (ця ознака характерна для ключових слів у позиції заголовка; 4) наявність чисельних контекстуальних асоціативно-семантичних зв'язків 3 іншими словами в тексті; 5) значне ідейне, смислове й сюжетне навантаження у творі; 6) участь у створенні структурно-семантичної єдності тексту, його цілісності.

Смислова вага ключових слів у тексті зумовлена тим, що вони формують систему лейтмотивів, які мають високий ступінь „під’єднання” до текстових

${ }^{9}$ Н. С. Болотнова, Филологические анализ текста, пособ. для филологов, Томск 2003, с. 138.

${ }^{10}$ Ю. Н. Караулов, С позиций рецептивной языковой личности (Идиоглосса в структуре текста и в восприятии читателя), [в:] Слово Достоевского, Москва 2001, с. 158.

${ }^{11}$ Н. С. Болотнова, Указ. источник, с. 31. 
смислів завдяки потужній мережі зв'язків та відношень, що індукує повторюване слово, а отже, вони є провідними носіями смислу, утворюючи своєрідний смисловий каркас, на якому тримаються основні ідеї тексту. У статусі найменувань, що формують лейтмотив (тему), для них характерна динаміка смислового наповнення - від звичайного номінативного значення слова до текстуально значущого. Дослідники відзначають, що нова містка семантика ключового слова „народжується всім смислом тексту, його семантичною темою” 12 .

Ключовий знак має формальне вираження - найчастіше певною лексемою або знаками, що виникають унаслідок унікальних процесів, притаманних лише конкретному тексту. Ключові слова тексту зазвичай мають концептуальне навантаження й найчастіше є лексичними репрезентантами текстового концепту. Отже, концептуальний аналіз тексту передбачає насамперед з'ясування набору ключових слів (також їхніх спільнокореневих слів та синонімів) як номінацій концептів. Смисловий потенціал концептів 3'ясовуємо шляхом дослідження текстового функціонування ключових слів - репрезентантів концепту, а потім виявлення мовних одиниць, що пов'язані з ними і вербалізують їхнє смислове наповнення. Засоби організації такого загального смислу можуть бути багатоманітними, його конструюють різні текстові одиниці, а їхній аналіз через виявлення визначеного і сталого комплексу семантичних ознак дає змогу окреслити сутнісні риси світу, які моделює автор у творі, визначити його підтекст і наскрізні образи.

Співвідношення концепту з текстовими одиницями, тобто з планом вираження всієї лексико-семантичної парадигми його імені ${ }^{13}$, дає змогу подати його у вигляді концептуальних полів - множини мовних одиниць, об'єднаних спільним значенням, загальним компонентом їхньої семантики. Ключові слова як змістовно-тематичні домінанти тексту „володіють властивістю утворювати смислові згустки, своєрідне семантико-тематичне поле, але поле, релевантне лише в цьому тексті, об'єднаному темою і основною ідеєю твору"'14. Спостереження над текстовою матерією, у якій усе взаємопов'язане й взаємообумовлене, дало науковцям змогу обгрунтувати продуктивність застосування до вивчення тексту категорії поля: „Польовий підхід до опису мови визнаний перспективним і в зв'язку з можливістю аналізу різнорівневих одиниць в експлікації загальної ідеї, і в зв'язку зі зміною наукової парадигми, яка передбачає звернення до комплексного вивчення лінгвістичного об'єкта. Це набуває особливої актуальності в дослідженні текстових явищ і категорій”"15.Традиційно під терміном „поле” розуміють сукупність мовних одиниць, що об’єднані спільністю змісту й відображають поняттєву, предметну чи функціональну подібність позначуваних явищ, унаслідок поле постає як спосіб існування й групування лінгвістичних елементів із загальними (інваріантними) властивостями ${ }^{16}$. Відзначимо, що в сучасній лінгвістиці це поняття застосувують переважно для найменуван-

12 Л. А. Новиков, Современный русский язык. Теоретический курс: Лексикология, Москва 1987 , c. 124 .

${ }^{13}$ С. Г. Воркачев, Культурный кониеет и значение, [в:] Труды Кубанского государственного технологического университета, Сер. Гуманитарные науки, Краснодар 2003, т. 17, вып. 2, с. 274.

${ }_{14}$ Ю. Н. Караулов, Словарь Пушкина и эволюция русской языковой способности, Москва 1992 , c. 158.

${ }^{15}$ Н. И. Беляева, Текстовые категории и принцип поля в их изучении (на материале рассказа Ю. Нагибина „Терпение”, [в:] Проблемь исследования слова в художественном тексте, Ленинград 1990, с. 73.

${ }^{16}$ Г. С. Щур, Теория поля в лингвистике, Москва 1974. с. 19; А. М. Кузнецов, Поле, [в:] Языкознание. Большой эничиклопедический словарь, Москва 1998, с. 380-381. 
ня сукупності мовних одиниць, що утворюють деяку семантичну спільність. Вони об'єднані загальною семантичною ознакою, спільним компонентом значення, що інтегрує одиниці поля і зазвичай виражений лексемою з узагальненим значенням, яка складає ядро поля.

Дослідження польових утворень базується в цій статті на текстоорієнтованій методиці. Власне мовні семантичні поля формуються в результаті аналізу текстів, але об'єктом дослідження є саме́ польове утворення, а текст виступає засобом його структурування. Вивчення текстового поля переміщує фокус дослідження на сам текст, а поле є способом його інтерпретації. Л. Чернейко пише, що текстовий концепт формують концептуальні ознаки (смисли), склад яких організований за принципами польового утворення. Дослідниця так описує зміст концептуального поля: „Концепт — це конструкт, що репрезентує асоціативне поле імені, але не рівний йому. Концепт — це парадигматична модель імені, що включає й логічну структуру його змісту, й сублогічну. Ці структури виводять відповідно і з вільної сполучуваності імені, і з невільної, тобто iз синтагматичних відношень імені, фіксованих у тексті" 17.

Н. Болотнова вбачає в застосуванні польового підходу основний засіб вивчення концептуального змісту: „Уважаємо, що виділення концепту (концептуальний аналіз) можливе на основі текстових асоціативно-смислових полів, організованих концептуально й стимульованих лексичними структурами різних типів"

У цьому дослідженні поняття „концептуальне поле” застосовуємо до впорядкованої множини мовних одиниць — концептуальних ознак (компонентів, смислів), які формують один з аспектів концептуального змісту; вони згруповані навколо ключового слова. Концептуальний аналіз тексту є таким способом його дослідження, у якому точкою відліку є поняттєві категорії - концепти, а мета дослідження - 3'ясування способів їхньої об'єктивації.

Аналіз текстових масивів передбачає встановлення засобу експлікації концепту - концептуальної ознаки (репрезентована словом, рідше - словосполученням, реченням), що синтагматично чи парадигматично пов'язана 3 ключовою лексемою і розміщена в найближчому контексті - зазвичай у межах того самого речення, рідше - в одному з кількох наступних, що, повторюючись у певних контекстах, сполучає їх у рамках типових текстових ситуацій. Концептуальні ознаки (звичайно сюди включаються і синонімічні найменування), об'єднані семантичною спільністю, формують єдиний семантичний простір - концептуальне поле, що є складником концепту. Таким чином, моделювання концепту здійснюємо на основі узагальнення й систематизації регулярно повторюваних у тексті однорідних концептуальних ознак, що його репрезентують, які й моделюють семантичні поля та демонструють його суттєві риси. „Дослідження концепту в тексті передбачає враховувати поряд із парадигматичними переважно синтагматичні зв'язки слів. Концепти художнього тексту формуються на синтагматичній основі, мають внутрішньотекстову синтагматичну природу... Концептуалізація, або методика експлікації концептуалізованої сфери художнього тексту, базується на семантичному виведенні їі компонентів iз сукупності мовних одиниць, які розкривають одну тему, мікротему. 3 цієї причини концептуальний простір тексту формується на більш високому рівні

17 Л. О. Чернейко, Лингво-философский анализ абстрактного имени, Москва 1997, c. $512-513$.

${ }^{18}$ Н. С. Болотнова, Указ. источник, с. 83. 
абстракції - на основі злиття, зближення, стягнення спільних ознак концептів, що репрезентуються на поверхневому рівні тексту словами й реченнями однієї семантичної сфери" 19 . Подібне бачення моделювання концептосфер демонструють дослідження М. Пименової: „Реконструкція структури концепту відбувається шляхом найбільш повного виокремлення можливих ознак, що можуть бути об'єднані за загальною для них видовою або родовою асоціативною характеристикою"20.

Отже, концептуальне поле об’єктивують лексеми, вільні та стійкі словосполучення, що формують спільний семантичний простір. Воно системно організоване, включене в мовну картину світу твору як структурований багатокомпонентний фрагмент тексту. Характеристиками польового утворення $\epsilon$ стійкі текстові зв'язки слів або їхніх окремих значень, системний характер цих зв'язків, взаємозалежність і взаємовизначеність лексичних одиниць, відносна автономність. Воно розкриває лише один визначений аспект концепту, і тільки сукупність концептуальних полів, що складають його концептосферу, достатньо повно передає його текстовий зміст. Межі концептуального поля за своєю природою відносні й можуть коливатися залежно від обраного для дослідження матеріалу.

Актуальним для з'ясування змісту концепту є поняття концептуальної парадигми. Моделювання концепту „включає визначення базових компонентів його семантики, а також виявлення сукупності стійких зв'язків між ними"21. Низка концептуальних полів, що групується навколо ключового слова, утворює план вираження концепту — концептуальну парадигму. Внутрішній зміст концепту внаслідок такого аналізу — це сукупність текстових смислів, організованих у концептуальні поля, що формують парадигматичне об' єднання, куди входить суттєва для його комунікативної реалізації текстова інформація.

Отже, у цій розвідці текстові концепти розглядаємо як редуковані позначення прототипових ситуацій ${ }^{22}$, або тем різного статусу. Мережа ключових концептів твору утворює основу його змістової структури. Основною формою репрезентації концептів, одним з основних методів його вивчення $є$ поле. Моделювання концепту — це моделювання поля слова-номінанта концепту, тому використання понять концептуального поля і концептуальної парадигми як об'єднання концептуальних полів створює передумову системного опису концептуального простору тексту, з'ясування шляхів вербалізації його важливих смислових домінант, цілеспрямованості його структур і прагматичної настанови повідомлення. Загалом концептуальний аналіз тексту передбачає виявлення набору ключових слів тексту, з’ясування змісту базових концептів твору й опис позначеного ними концептуального простору.

На основі описаного підходу в аналізі текстових концептів Нового Завіту використано таку методику. Перший крок - виокремлення ключових слів, а також їхніх дериватів і синонімічних найменувань за принципом частотності та 3 урахуванням особливостей змістового наповненням тексту. Ця процедура дає змогу визначити перший, так званий „зовнішній” концептуалізований шар текстової структури. Наступний етап демонструє дослідницькі процедури, спрямовані на висвітлення змісту концептуальних полів ключових слів. Та-

${ }^{19}$ Л. Г. Бабенко и др., Указ. источник, с. 58.

${ }^{20}$ М. В. Пименова, Душа и дух: особенности концептуализации, Кемерово 2004. с. 6.

${ }^{21}$ И. П. Михальчук, Конщептуальные модели в семантической реконструкиии (индоевропейское понятие „закон”), [в:] „Известия РАН”, Москва 1997, т. 56, № 4. с. 29.

${ }_{22}$ А. Вежбицкая, Язык. Культура. Познание, Москва 1996, с. 337. 
кий аналіз передбачає узагальнення всіх контекстів, у яких ужиті ключові слова — носії концептуального смислу - для виявлення характерних властивостей концептів, конструктивних елементів їхнього смислового наповнення. Розгляд та систематизація мовних засобів репрезентації концептів у тексті дозволяє виділити певні смислові єдності - концептуальні поля, кожне $з$ яких містить характеристику концепту. В інваріантній моделі концепт є межею узагальнення (інваріантом) плану змісту мовних одиниць, що покривають певну семантичну сферу. Зрозуміло, що великий за обсягом твір зазвичай демонструє актуальність цілої низки концептів, тому базою для подальшого етапу аналізу є система взаємопов'язаних концептів, вербалізованих у тексті.

У цьому дослідженні виходимо з уявлення про концепт як відносно сталу інформаційно-когнітивну сутність, що є носієм (концентратором) смислів певного дискурсу або певної системи знань. Лише актуальне й цінне в смисловому відношенні явище, яке отримує мовну фіксацію в парадигматично й синтагматично значній кількості мовних засобів, демонструє якості концепту. У цій науковій студії актуалізуємо трактування окресленого терміна як певної когнітивної абстракції, що узагальнює значення (смисли) системи своїх мовних реалізацій, так що конкретна форма концепту визначається певним інтервалом абстракції, у межах якого він є стійким та якісно визначеним через обсяг лексикосемантичної парадигми, яку формують мовні одиниці, що передають це поняття в тексті. Репрезентована на поверхні тексту велика кількість концептів входить функціональним корінням у глибинні текстові ідеї та в результаті виявляє ієрархічну систему смислів, що організують зміст твору, тому на третьому етапі концептуалізації текстового простору відбувається так зване ,занурення” в текст, здатне виявити глибинну й категоріальну зв'язність його елементів, декодувати, розгорнути й актуалізувати його внутрішню змістову структуру.

Оскільки концепт характеризується багатовимірною вбудованістю в систему концептуальних полів, він пов'язаний чисельними семантичними відношеннями і взаємодіями з іншими концептами, вписаний у систему зв'язків із ними ${ }^{23}$. Він входить у велику кількіть взаємопов'язаних поняттєвих сфер - концептуальних полів інших концептів, що семантично пов'язані між собою. Аналіз усієї сукупності полів, за якими розподілені концепти, встановлення відповідностей між їхніми компонентами дає змогу здійснити моделювання смислових домінант твору, його підтексту через текстову експлікацію суперконцептів. Суперконцепти є носіями ланцюгів смислів, виражених, звичайно, словами та словосполученнями, які формують інтегрований простір, що включає найменування однойменних семантичних полів. Аналіз тексту, що спирається на статистику цих найменувань, дозволяє побудувати відповідний багатовимірний індекс - лексикографічну систему основних домінантних понять (семантичних зон) тексту та їхніх зв’язків разом із їхніми кількісними характеристиками. Як смисловий портрет тексту розглядаємо фразові об'єднання кількісно рівноцінних семантичних домінант, а отже, таких, які мають рівнозначну смислову вагу в тексті, що дає змогу вибудувати цілісну систему їхньої смислової значущості. Суперконцепти тексту демонструють імпліцитну інформацію, на основі якої формуються смислові лінії глибинної семантичної структури тексту.

У системі концептосфери Нового Завіту суперконцептами є фразові об'єд-

${ }^{23}$ М. В. Никитин, Развернутые тезисы о концеептах, [в:] Bопросы когнитивной лингвистики, Москва 2004, № 1, с. 53. 
нання, що організовують глибинні текстові смисли на матеріалі досліджуваного тексту у вигляді ядерної, серединної та периферійної зон. Першу формують найменування концептуальних полів, що виявили найбільшу частотність у текстовій концептосфері, а отже, найбільшу смислову вагу. Друга й третя демонструють розбудову компонентів їхніх моделей на основі зменшення кількісного складу i, відповідно, текстової ваги. Отже, моделі суперконцептів Нового Завіту відтворюють такі текстові глибинні смисли цього твору:

Iсус Христос спасає людей через віру (найменування концептуальних полів різних концептів, що зустрічаються в тексті більше 10 разів);

Ісус Христос спасає людей через віру, прощзююч їхні гріхи й даруючи їм вічне життя в Небесному Царстві (додано ті концептуальні поля, що трапляються більше 5 разів);

Icyc Xристос пролив Свою кров і воскрес, щоб прощати, благословляти, зцілювати, освячувати й спасати людей, які покаялися в гріхах і хрестилися, через проповідь Свангелія, віру і благодать, даруючи їм вічне життя в Небесному Царстві (додано ті концептуальні поля, кількість яких більше або дорівнює 3).

Проведене дослідження продемонструвало, що концепти відіграють визначальну роль у забезпеченні когнітивної структури тексту. Вони є актуальними одиницями в системі текстових відношень, що репрезентують кванти структурованого знання і сформовані в тексті у вигляді складних смислових утворень, у яких виділяють три основні виміри: 1) компонентний (лексичний) вимір - система ключових слів, що реалізують у своїй семантичній структурі базові значення концептів, демонструючи актуальний ідентифікаційний текстовий пласт і одночасно маніфестуючи мовну складову когнітивного каркасу тексту; 2) текстовий (інтерпретаційний) вимір, сформований комплексними структурами - концептуальними полями, що демонструють текстові реалізації концептів; 3) смисловий (підтекстний) вимір, який виявляє основні домінанти твору, що вибудовані в ряди (ланцюжки) відповідно з їхньою концептологічною значущістю (вагою) і які репрезентують імпліцитну інформацію та моделюють основні смислові лінії глибинної структури тексту. Усі три виміри репрезентації концептів тексту формуються в контексті цілого твору: у них виявлені взаємозв'язки і взаємозалежності відповідних елементів. Запропонована методика дала змогу експлікувати комплекс глибинних смислів тексту Нового Завіту, детермінований його концептосферою. 